\title{
RADIO-ECHO SOUNDING OF MOUNTAIN GLACIERS
}

\author{
By I. A. Zотікоv, \\ (Institut Geografii AN SSSR, Staromonetny 29, Moscow rogor 7, U.S.S.R.)
}

V. S. Luchininov,

(Leningradskiy Ordena Lenina Elektrotechnicheskiy Institut im. V. I. Ulyanova (Lenina), Leningrad, U.S.S.R.)

Yu. Ya. Macheret,

(Institut Geografii AN SSSR, Staromonetny 29, Moscow rogo i 7, U.S.S.R.)

and L. A. Suchanov

(Fakultet Geografii, Moskovskiy Gosudarstvennyy Universitet im. M. V. Lomonosova, Moscow B-234, U.S.S.R.)

Abstract. Experiments on radio-echo sounding of mountain glaciers have been done on Lednik Marukh (west Caucasus), Lednik Bezingy and Lednik Dzhankuat (central Caucasus), Lednik Gergety (east Caucasus), and Lednik IGAN (Polar Urals) in 1967-7 I as a part of the I.H.D. programme. Radio altimeters operating at a frequency of $440 \mathrm{MHz}$ with a pulse duration $0.5 \mu$ s and with an assumed radio-echo system performance of $130 \mathrm{~dB}$ were used. The apparatus was operated from the ice surface (using sledge or vehicle) and partly from a helicopter. Some measurements have been made while the apparatus was being moved continuously along longitudal and transverse profiles of the glacier. Some of the measurements have been made at separate points on the glacier. The methods of measurement and interpretation have been worked out. Data on ice thickness, subglacial topography, and internal structure of some mountain glaciers have been obtained and compared with data got using other geophysical methods and thermal drilling. There is agreement between the results.

\section{STATISTICAL METHOD OF RADIO-ECHO SOUNDING TEMPERATE MOUNTAIN GLACIERS AND PORTABLE EQUIPMENT FOR THAT}

\author{
By L. A. Suchanov \\ (Fakultet Geografii, Moskovskiy Gosudarstvennyy Universitet im. M. V. Lomonosova, \\ Moscow B-234, U.S.S.R.)
}

Abstract. Field experimental data show the possibility of using standard radio-echo sounding equipment of relatively low power to sound through a temperate mountain glacier. The main problem of sounding is the interpretation of echo signals, because they are a mixture of visually indiscernible echoes from the bed and from inhomogeneities in the body of the glacier. To get information about ice thickness and other things from such echo data, a method based on a statistical analysis of echo-signal fluctuations is proposed. As a main criterion the stability of echo-signal statistical characteristics is used. 